\title{
and Health (ICASSETH 2019) The Role of Corporate Social Responsibility on Education Funding in Palm Oil Plantation PT. Astra Agro Lestari, tbk (PT. AAL,tbk) in Indonesia
}

\author{
Mesta Limbong* \\ Pascasarjana \\ Universitas Kristen Indonesia (PPs-UKI) \\ Jakarta, Indonesia \\ *mesta.limbong@uki.ac.id
}

\begin{abstract}
This study analyzes the role of Corporate Social Responsibility (CSR) in financing learning activities as well as facilities and infrastructure which is needed by schools. There are financial assistances given by regional orders namely Regional Operational Costs (BOSDA), and School Operational Assistance (BOS) from the state. Unfortunately, the fees received from BOSDA and BOS are not sufficient for school operations. Qualitative research method was used in this research, data obtained through observation, interviews and records. Based on the data obtained. As a result, $95 \%$ of expenditure on school operations was obtained from company CSR, $5 \%$ from BOS and BOSDA funds. It was conducted by the den school in the PT. Astra Agro Lestari, tbk (PT. AAL), tbk in Central Borneo in Indonesia. The largest cost of all financing activities related to schools is from the oil palm plantation company PT. AAL, tbk.
\end{abstract}

Keywords: education funding, corporate social responsibility

\section{INTRODUCTION}

The area of oil palm plantations in West Kalimantan is certainly absorbed a large amount of workforces. Including who work in schools in the area of oil palm plantation environment. Based on observation data for 2016 - 2017 in oil palm plantations, the number of workers who help the academic and non-academic fields around 377 people. They work as: teachers who teach according to their fields of study, librarians, laboratory assistants, administrative staffs, drivers, gardeners, driver's assistant. The budget is calculated every year according with the annual program and activity planning, and the one who responsible for calculating the costs required for company operations is the Corporate Social Responsibility (or CSR) region cooperates with the central CSR and every school principal in every region $[1,2]$.

CSR as an extension of the company responsible is to facilitate overall education funding. To calculate the budget / funding required for each school, it is determined based on annual planning conducted by the company (CSR) and collaborated with the school principal and involved teachers in the school, in order to equip students. All schools in the plantation area are not permitted to collect education fee, which means that all students who attend school in the plantation area do not have to pay the fee.
The question is how is the company's role through CSR in funding 9 years of basic education at PT. AAL, tbk in Central Kalimantan in Indonesia? Are there other costs obtained by the school apart from the company in funding 9 years of basic education at PT. AAL, tbk in Central Kalimantan in Indonesia?

\section{A. Corporate Social Responsibility (CSR)}

Since the issue of sustainable development around 1992 stated that the presence of the company does not have a positive impact on the environment, instead of exploit, thus emerges corporate social responsibility (CSR), with the aim of being able to bridge the needs of surrounding communities and the interests of the company. It cannot be denied that there is a gap between local communities and migrant communities who work in the company.

CSR the actions of a firm to benefit society beyond the requirements of the law and direct interest of the firm [3]. Hendrik B. Untung explained that Kaltim Prima Coal (KPC) carried out seven areas of CSR namely as agro business, education, health, utilization of small and medium micro businesses, infrastructure, nature and cultural preservation, and strengthen the impact of community and government. KPC built schools, brought in teachers; the operational costs for several years were done by the company.

The presence of CSR companies should ideally make a continuum contribution to the ongoing life of migrants and local communities that live with better hopes or better relationships with all parties involved.

Corporate social responsibility as defined by the European Commission and quoted by Abiodun in Antule et al., is a concept where companies integrate social and environmental concerns in their business operations and in their interactions with their stakeholders on a voluntary basis "follows increasingly a ward that responsible behavior brings sustainable success [4]. It can be said that the presence of the company in the community is able to integrate the company's life and community life around socially. And of course, there is awareness of behavior so that aspects of business and society are sustainable. 
Limbong conducted a study on CSR related to: planning, organizing, implementing, monitoring [2]. In its implementation how to apply the social responsibility program that has been designed, how to conduct supervision and the findings related to education by doing: build the school physically, facilities, teacher's place to stay, collaborate with third parties.

Mesta Limbong's findings in (2008-2010) found that there were expense expenditures such as: monthly income from workers who assist the schools, transportation facilities for pick-up students, for school development, assistance for nearby schools, scholarships, place to stay facility for teachers, and recruitment for new workers [2].

Education funding standards as stated in PP 19/2005 as a standard that ruled the components and the total of the operating costs of education units for one year. Education funding consists of investment costs, operating costs, and personal costs. The investment costs of the education unit as referred above cover the costs of providing facilities and infrastructure, human resource development and permanent working budget. Personal costs as mentioned above include education costs that must be spent by students so they are able to follow the learning process regularly and continuously. The operational costs of the education unit as referred above include the salary of educators and education personnel as well as all benefits attached to salaries, consumable educational materials or equipment, indirect educational operational costs in the form of electricity, water, telecommunications services, maintenance of facilities and infrastructure, overtime pay, transportation, food, tax, insurance, etc. Republic of Indonesia Government Regulation number 32 of 2013 related to national education standards in article 1 paragraph 11 explained that the funding standard is a criteria regarding the components and the total of the operational costs of education that is used for one year.

, talks about the planning of school operational assistance (BOS) how to improve the education quality of primary school in Palangkaraya was arranged through school committee meetings, the presence of parents' representatives, prepare the school budget work plans (RKAS). It is hoped that it can improve students' achievements and school performance. With the existence of BOS, it is expected that no children will drop out from school. With BOS it is greatly expected to support the availability of learning support facilities as well as improve the quality of teachers.

The broadest definition of corporate social responsibility is concerned with what it or should be the relationship between global corporation, government, countries and individual citizens [5]. More locally the definition concerned with the relationship between a local society in which it resides or operates. Another definition is concerned with relationship between corporate and its stakeholders.

Corporate social responsibility (CSR) is a self-regulating business model that helps a company be socially accountableto itself, its stakeholders, and the public [6]. By practicing corporate social responsibility, also called corporate citizenship, companies can conscious of the kind of impact they are having on all aspects of society, including economic, social and environmental.

It can be concluded that the function CSR within the company is as an extension of the company. The job is for the company and surrounding communities have harmonious relations. Companies experience an increase in the financial aspect, even though people expect the same thing. There is an impact on life. Having a positive impact means that workers and the community are expected to create a better generation.

So, CSR is part of a company that is responsible for the social needs of the community, such as: meeting the needs of schools that exist in the plantation itself and the communities around oil palm plantations.

\section{B. Education Operational Funding}

By stating about financing, schools pay attention on funding for schools, measure quality, and through financing school can measure achievement, distributing according to plan, and how to conduct evaluation, Minister of Education and Culture Regulation No. 18 of 2019, said the funds that is received in the first quarter can be used for: funding books used in schools, developing learning media, developing things that related to standards which is used to improve the quality of learning in schools, and extra-curricular, payment for resource services, purchase of books, office supplies, all of them using school operational assistance funds which are usually called (BOS) [6]. Almost all funds are only used to support the learning process to be in a good quality. BOS is a fund provided by the central government, which in reality is not sufficient to be used to support a qualified learning process. Even schools do not collect funds from students.

Local governments realize that BOS alone is not sufficient to fix the school quality. Because the school's operational budget requires a big funding. The regions are aware of and carry out further development by developing a pilot program to strengthen the efforts of the local government by developing Regional School Operational Assistance, called as BOSDA.

- Funding according to the National Education Standards Agency http://bsnp-indonesia.org/standar-pembiayaanpendidikan/,2019, the intended financing includes: investment financing, operational and personal funding [7].

- Investment financing is meant for: financing the facilities and infrastructure, providing opportunities to develop human resources, as well as permanent work budget.

- Personal costs are costs which provided by the students to follow the learning process regularly.

- Operating costs, such as for salary, overtime, consumable things, water, services, food, taxes, transportation, insurance, maintenance of facilities and infrastructure.

Financing upper secondary education unlocking 12 years of education for all in Malala fund, 2015, the core commitment of the global partnership for education (GPE) is the basic 
education. An expansion of its scope fund upper secondary education will be needed to help mobilize and coordinate the additional funding needed to support 12 years of quality primary and secondary education for all, building on a year of pre-primary. This expansion should be in supper of nationally driven education sector plans which focus on the full courses of education from pre-primary to upper secondary.

Education funding standards as stipulated in PP 19/2005 about standards that ruled the components and the total amount of the operating costs of an education unit that are valid for one year. Education funding consists of investment costs, operating costs, and personal costs. The investment costs of the education unit as referred to above cover the costs of providing facilities and infrastructure, human resource development and permanent working capital. Personal costs as mentioned above include education costs that must be spent by students to be able to follow the learning process regularly and continuously. The operational costs of the education unit as referred above include the salary of educators and education personnel as well as all benefits attached to salaries, consumable educational materials or equipment, indirect educational operational costs such as electricity, water, telecommunications services, maintenance of facilities and infrastructure, overtime pay, transportation, food, tax, insurance, etc. Republic of Indonesia Government regulation number 32 of 2013 related to national education standards in article 1 paragraph 11 explained about the funding standard and also about the education's operational costs for one year.

Mesta Limbong's finding in (2008-2010) found that there were expense expenditures such as: monthly income from workers who help the school, transportation facilities for pickup the students, for school development, assist nearby schools, scholarships, and place to stay facilities for teachers, and also the recruitment of new workers.

Conducted a study on regional operational assistance (BOSDA) [8], the finding shows that the delay in distributing funds as a problem. This finding provides information that BOSDA tends not to be received by the schools on time. This can affect school plans and all of the planning can't be done optimally, because the funds are not received on time.

Her discussion of financial analysis, investment analysis, corporate finance, financial management [9]. Explained, that CSR has economic responsibilities, pay attention to the benefits that was obtained and also to applicable laws. The discussion related to financing is very clear, in the discussion. This shows that the financing schools in the plantation area are calculated by the company. Starting from operational finance, investments related with facilities and supporting facilities, which contribute to the quality of Education.

Education Policy Analysis UNESCO Hand Book (file://C:/Users/USER/Downloads/221189eng.pdf), financing in the context of education sector policy can be understood as both a policy instrument in the pursuit of education development goals and also as a policy in itself as part of wider sector policy [10]. It concerns the way financial resources are mobilized, allocated and used toward provision of education services.
It can be concluded that funding is the availability of funds that can be used to realize the activities that have been designed according to the needs of learning activities in school, and will facilitate the achievement of educational goals.

\section{RESEARCH METHODS}

The purpose of this study provides an overview of the role of Corporate Social Responsibility (CSR) of PT. Astra Agro Lestari Tbk (PT.AAL, tbk) towards financing all Education activities carried out in schools in the Central Borneo region in Indonesia

This is a qualitative research. Data collection, data reduction, data presentation, then conducted verification before withdrawal the research findings [11]. Data was obtained through: observation, interview and recording. Next, the triangulation and data reduction was done [1]. Data collection was done in February 2019.

\section{RESULTS AND DISCUSSION}

The study was carried out in the region of Central Kalimantan at an oil palm plantation. The research data was obtained from: data documentation was carried out to find out "The role of CSR in supporting education form in oil palm plantations of PT. AAL, tbk in Central Kalimantan. The research data findings are qualitative descriptive analysis and supported by a number of statements compiling the research analysis.

With the increase area in of oil palm plantations, it is to be curtained to have an impact on employment. Productive-age workers have children in school age. Public schools tend to be located outside the area of oil palm plantations. For this reason, the company facilitates workers by providing education institution in the plantation and managed it.

The result of the research in Limbong, recorded the number of schools in Bumitama Gunajaya Agro (BGA) oil palm plantations is 35 , consists of 11 elementary schools, 5 junior high schools, 1 vocational school and other kindergarten / early stage education [2]. On average, each schools, both elementary and junior high schools, the number of teachers are between 10 and 14 teachers, 3-4 kindergarten educators, means that the total number of educators from kindergarten, elementary, junior high and vocational schools is around 267 educators with status as permanent employees and non-permanent employees, and public employers. Likewise, with the administration staff and the garden assistant, cleaning service, if in an average of 2 per school, means that the total number of educational staff for all schools in the BGA is around 70 people. Not to mention the other workers as: driver, driver assistant. If each area in the plantation has four vehicles, it means that the total number of workers outside of teaching and education staff is up to 40 people. The number of workers who directly deals with schools starting from teaching workers, staffs such as: administration staff, library staff and drivers and driver's assistant is estimated at 377 people.

From the number of students who is in average of 250-300 students and there is no fee demanded to them. They attend education for free, which means it is the responsibility of the 
company. From this explanation it can be concluded that the funding used for: salary for educators and non-education personnel, renovation of classrooms / buildings and the additional space, shuttle vehicle facilities and health clinics are the responsibility of the company. In other words, BOS and BOSDA are used for school operations. There are no fees from students. BOS and BOSDA directly supports the ongoing learning process in schools.

The study was conducted at schools in the Central Kalimantan region within the palm oil plantation company PT. AAL, tbk consists of 3 elementary schools and 2 junior high schools with a total of 47 teachers. All teachers have S-1 / D-4 education backgrounds. Educational staff's number, such as drivers, driver's assistant, laboratory assistants, school cleaners is around 20 people. The income of educators and education staffs become responsibility of the company, 67 people monthly. More detailed in table 1 is the responsibility of the company.

TABLE I. SCHOOL ACTIVITIES FUNDING

\begin{tabular}{|l|l|l|l|l|}
\hline \multirow{2}{*}{ No } & \multirow{2}{*}{ ACTIVITY } & \multicolumn{3}{|c|}{ Funding } \\
\hline & & BOS & BOSDA & CSR Company \\
\hline 1 & Learning Activity & $\square$ & $\square$ & \\
\hline 2 & Mid-Test & $\square$ & $\square$ & \\
\hline 3 & Final-Test & $\square$ & $\square$ & \\
\hline 4 & $\begin{array}{l}\text { Lattice } \\
\text { Arrangement }\end{array}$ & $\square$ & $\square$ & \\
\hline 5 & Design Questions & $\square$ & $\square$ & \\
\hline 6 & Remedial & $\square$ & $\square$ & \\
\hline 7 & Daily Test & $\square$ & $\square$ & \\
\hline 8 & Result Analysis & $\square$ & $\square$ & \\
\hline 9 & Stationery & $\square$ & $\square$ & \\
\hline 10 & Physical Activity & $\square$ & $\square$ & \\
\hline 11 & Purchasing Books & $\square$ & $\square$ & \\
\hline 12 & Textbooks & $\square$ & $\square$ & \\
\hline 13 & $\begin{array}{l}\text { Assignment } \\
\text { Books }\end{array}$ & $\square$ & $\square$ & \\
\hline 14 & Project & $\square$ & & \\
\hline 15 & $\begin{array}{l}\text { Developing } \\
\text { teacher's }\end{array}$ & $\square$ & $\square$ & \\
\hline 16 & Teacher Salary & & & $\square$ \\
\hline 17 & $\begin{array}{l}\text { New Student } \\
\text { Admission }\end{array}$ & $\square$ & $\square$ & \\
\hline 18 & Art & $\square$ & $\square$ & $\square$ \\
\hline 19 & Teacher Salary & & & $\square$ \\
\hline 20 & Staffs Salary & & & $\square$ \\
\hline 21 & $\begin{array}{l}\text { Driver } \\
\text { Driver's Assistant }\end{array}$ & & & $\square$ \\
\hline 22 & $\begin{array}{l}\text { School Vehicle } \\
\text { Maintenance }\end{array}$ & & & $\square$ \\
\hline 23 & $\begin{array}{l}\text { Build school } \\
\text { buildings }\end{array}$ & & & $\square$ \\
\hline 24 & Vehicles & & & $\square$ \\
\hline 25 & Teacher's House & & & $\square$ \\
\hline 26 & Computer & & & $\square$ \\
\hline 27 & Laboratory & & & $\square$ \\
\hline 28 & Library & & & $\square$ \\
\hline 29 & $\begin{array}{l}\text { Health Clinic and } \\
\text { facilities }\end{array}$ & & & $\square$ \\
\hline 31 & $\begin{array}{l}\text { Teacher's } \\
\text { Recruiting }\end{array}$ & & & $\square$ \\
\hline 32 & Training & & & $\square$ \\
\hline 33 & Books & & $\square$ \\
\hline & & & $\square$ \\
\hline
\end{tabular}

From table 1, items 19 to point 33 are the responsibility of the company to be funded. The funds are used for: teacher assessment, administration staffs, vehicle facilities, maintenance of school physical facilities and teachers' house facilities, libraries, clinics, teacher seminar, teacher recruitment, teacher and education staffs training as well as other supporting facilities, such as; books and more.

Development related to the evaluation/assessment of students, such as: lattice preparation, daily tests, mid-test, design question, daily test, follow-up assessment's results: analysis, remedial, enrichment. Consumables such as stationery, pencils, pens, learning support stationery, master books. Purchasing books, textbooks, assignment books, books to complete the library and funds for other assessments, such as: portfolio, projects, and assignments. Extra-curricular activities funds are obtained from company. Such as: sports facilities that do exist in the company environment. Annual planning at school does not yet take into account for funding: improving teacher quality. Funds are limited only to routine activities, such as: for teacher meetings, group meetings of subject teacher (MGMP), routine meetings of school principals.

The annual school programs which are funded from the BOS and BOSDA funds: the development of education staffs is only limited to general activities, such as: teacher work groups, principal work groups. While activities for the development of teachers is from the company.

It can be concluded, that the company's CSR is responsible for facilitating the ongoing learning process. Indeed, there are still obstacles such as: operational funds are not available, it is difficult for teachers to participate in enrichment and debriefing activities, in management there is still needed a clear line between corporate responsibility / CSR and school duties and responsibilities. Sports equipment.

Funds that have been provided from the central and the regions government tend not to be allocated for teacher development. Rather the operational funds help the learning process and tend to used up. For activity that gives extra value to teachers: budgeted from the company, for example attend seminars, comparative studies. The largest funding around $95 \%$ is from companies. Every month certainly be given to the salary of educators and educational staff.

\section{CONCLUSION}

95\% of the largest funding is the responsibility of the company (CSR). Funding for additions, improvements of school's space, teacher opinions, teacher recruitment, vehicle and shuttle facilities, student clinics but is not part of the school report yet. 5\% fund from the central and regional governments to support school operations. There is no fee collection from students.

Measured funding and adjusted to all learning activities designed for one year, will greatly affect the quality of education, and CSR responsibilities as an extension of the company in providing routine funds every month, and improvement of school facilities have become the commitment's proof of the company. 


\section{REFERENCES}

[1] M. Raharjo, "Studi Kasus Dalam Penelitian Kualitatif," Univ. Islam Negeri Maulana Malik Ibrahim Malang, 2017.

[2] M. Limbong, “The Role Of Corporate Social Responsibility In Quality Improvement Of 9-Year Education,”J. Educ. Res. Adm. Manag., 2017.

[3] J.P. Doh, F. Luthans, and J. Slocum, "The world of global business 1965-2015: Perspectives on the 50th anniversary issue of the Journal of World Business: Introduction to the special issue," Journal of World Business, 2016.

[4] P. Antule, G. Nangoi, and I. Suwetja, "Analisis Penerapan Corporate Social Responsibility Terhadap Profitabilitas,” J. Ris. Ekon. Manajemen, Bisnis dan Akunt., 2016

[5] G. Aras and D. Crowther, "Governance and sustainability: An investigation into the relationship between corporate governance and corporate sustainability," Manag. Decis., 2008.
[6] D. Murphy and A. Ng'ombe, "Corporate social responsibility," in Corporate Social Responsibility and Urban Development: Lessons from the South, 2009.

[7] http://bsnp-indonesia.org/standar-pembiayaan-pendidikan/,2019

[8] A. Fitri, "Pengelolaan Dana Bantuan Operasional Sekolah (Bos) Sekolah Dasar Negeri Kecamatan Mandiangin Koto Selayan Kota Bukittinggi,' J. Adm. Pendidik., 2014

[9] P. Vernimmen, Y. Le Fur, M. Dallochio, A. Salvi, and P. Quiry, "What is corporate finance?," in Corporate Finance, 2017.

[10] (file:///C:/Users/USER/Downloads/221189eng.pdf Education Policy Analysis UNESCO Hand Book,

[11] M.A. Miles, "Miles and Huberman (1994)- Chapter 4.pdf," in Qualitative Data Analysis: An Expanded Sourcebook, 1994. 